\title{
Foreign Language Learning, Environment, and their Influence on Moslem Teenage Learners' Identity
}

\author{
Dwi Wulandari ${ }^{*}$, Afif Noor $^{2}$ \\ ${ }^{1}$ English Department, Faculty of Humanities, Diponegoro University, Indonesia \\ ${ }^{2}$ Islamic Law Department, Sharia and Law Faculty, Walisongo Islamic State University, Indonesia
}

\begin{abstract}
This study is aimed at looking at how the environment of foreign language learnings affect the identity formation of the teenage learning them. English and Arabic languge, the language learnt formally by teenage at madrasa, are compared to find out which influences what in learners identity. The study shows that learners see both languages in a positive attitude, though in a different manner. English is seen with pretty much respct of the symbols of modernization, and therefore the learners are more cautious in using them, although some studies report that there is no negative influence of English on learners' identity. On the other hands, Arabic language is easily view as part of learners' identity as it is closely related with Islam. Though the learners perceive the language in a quite different manner, the result of their learning aimed at communication show quite similar result, as both processes show the difficulty in enhancing quick achivements.
\end{abstract}

\section{Introduction}

As many cultures acknowledge, persons aged for secondary schools fall in the group of being teenagers. However, in Islamic terms, such persons are considered adult, as they are on the condition marked for living their lives as adults. Considered as adults, the main assumption is that such persons are already developed a complete sense of who they are, or in other words they are aware of their identity.

At the same time however, the complacency of their life stage has trigerred different perceptions on their selves being, as they are transfering themselves from children into adults. The many worlds they are living in, the home, the school, the neighbourhood, may develop particular sense of being which may support each other, or they may also conflict with each other, not to mention the hormone and the physical changes which play important part in forming their senses. All of these senses and experiences in the teenages' lives have shaped their views about their worlds and formed their identity as a whole.

By the time these teenages enter the secondary school year, they will bring with themselves their identity, some of whom may have a solid one, and some other may be easily

* Corresponding author: wulandaridwi76@gmail.com 
adjusting with the environment. Their encounter with new experiences, in this case with the chances of learning foreign language, may affect the formation of their identity. As of many Indonesian students, teenages mostly learn English when they start their secondary level or junior high schools, though many others have started to learn it in elementary schools. In Islamic Institution, the foreign language learned will be added with Arabic language lesson, though again, many of the students have also experienced the learning since their elementary school.

The exposure of both English and Arabic learning along with their learning environment has at particular extend influenced the views of the learners in a way that it may subdue the developing identity or otherwise to strengthen it. This article will take a look at those particular issues of how foreign language exposure and the environment of learning affect the development of moslem learner identity.

\section{Foreign Language Learning}

The terms of foreign language learning sould be differentiated the terms of second language learning as the implication for the learning result will also be different. Foreign language learning is a term used for the context where the language learnt is not the language used for daily communication [1]. An example for this situation will be learning English in Indonesia, where English is not spoken for daily communication. This condition is differentiated with second language learning where the language learnt is used for daily communication, for example, learning English in USA where English is used for daily communication [1].

The context is named differently because the implications its brought to the learning experiences and result are also different. In foreign language learning, as the language learnt is not used for daily communication, the exposure toward the language will be limited. The condition where the learners are forced to use the language will also be very limited. Therefore, the degree of exposure as well as the amount of anxiety will be lessen, and limited mostly on the classroom situation.

As the exposure to use the language in real communication is limited, it will limit the availability of authentic learning materials [2]. This will not only limit the chances to practise using the language but it will also prevent the learners to interact with the culture where the language is originated, or the interaction will be facilitated by the use of technology and social media. These, along with what learners perceive with the learning environment will shape their attitudes toward the language they learn [3].

\subsection{English learning in Islamic Institutions in Indonesia}

In Indonesia, English is learnt as compulsory subject in all of secondary schools. In fact, English has been learnt in Indonesia since its independence, though limited on particular schools due to the limited available teachers and related resourches. However, the actual policy to include English on schools' curriculum began at 1946, and it is legally supported by the Minister Decree No. 096/1967 stating that English is a compulsory course in secondary schools with the goal to equip the students with "working knowledge of English" [4]. Therefore, English is officially learnt in all secondary schools including the 'madrasa', the Islamic institutions throughout Indonesia.

Madrasa itself, principally is inline with the common schools, with extra notion given to the fact that madrasa has Islamic charateristics attached to it. This holds true with the establishment of Government Act no. 2 of 1989 on the National Education System, in which it clarifies the position of madrasa as public schools holding Islamic characteristic in our national educational sistem [5]. 
With such position, madrasa then behaves in the same way as public schools, including the curriculum it applies although the amount of time exposed to each subject is probably adjusted with the principle concept of the schools. As an institution having Islamic characteristic, Islamic subjects cover $30 \%$ of the whole subjects [5], and that makes madrasa rather different from the regular schools, in which the Islamic subject is only given less than $5 \%$ out of the whole subjects. Because of the $30 \%$ coverage on Islamic subject, the time allocated for English and other regular subject then is not given as much as in the regular schools.

Although madrasa students have less amount of time to dwell with English, the curriculum that is applied at madrasa is the same as the regular schools. They are also using the same text books used in regular schools. The activities covered in the books are mostly targeted for communication, as the curriculum is designed based on communicative approach where "the competence standard of learning are done through oral expression of meanings of interpersonal and transactional discourse in formal and non formal communication" [6]. With such target, most books offer lessons and exercises for communicative models and interactions. For exmple the text book mostly used in junior high schools and madrasa tsanawiyah is When English Rings Bells [7], in which all of the units offer exercises on conversations, which include greetings, introduction and simple descriptions of habits.

Communicative competence as aimed by the approach is most advantageous when it is taught by acknowledging the culture in which the language is spoken, because through oral communication there can be various hidden gesture and language norms that can be learnt [8]. In foreign language learning, this hardly can be seen except through the help of the media. Even so, the abscence of actively participating in real life communication, and viewing only what is shown through the media will make learners generating their opinion and attitudes towards what is only shown on the surface of the culture, and never really grasp the ideal picture of the culture.

Not only that the students at madrasa undergo the difficulty to interact with the real culture, the time allocated for learning English is limited mostly in class with only few chances to practice. This shorthcoming will result in the awkwardness in producing the language as many students will feel anxious and prefer to keep silent to avoid not just making mistakes [9], but also embarassing themselves. Such experiences in learning along with the exposure of 'viewed culture' may create learners' particular attitudes toward the language, and the people speaking that language.

\subsection{Arabic language learning in Islamic Institution Indonesia}

Quite in contrast with English learning, Arabic language learning somehow gains more confident environment, although the result of the learning is not pretty much different from that of English. As what may be easily understood, Arabic is the language used for performing 'good rituals' in Islam, and the sources of knowledge to learn values in Islam, and therefore, many moslems learn the language as the source of their faith.

Originally, Arabic language was learnt in traditional pesantren, the oldest Islamic institution whose main task was to informally teach the reading of Qur'an. Hence, the focus was teaching the Arabic grapheme. Later on, it developed into teaching Islamic values as they were written in Qur'an, hadist, and other Islamic sources of knowledge. As Islam continue to spread in Indonesia, traditional pesantrens also spread throughout Indonesis. They are then evolved into similar yet different type of insitutions, including modern pesantren and madrasa, though many still remain as being traditional.

There are three important things to note in the learning of Arabic language. First, almost all moslems learn to read the Arabic grapheme, even without being the students of any 
institution, as they need to be able to read the Qur'an. However, the ability to read the grapheme is not always accompanied by the ability to understand its meaning, as moslems believe that reading the Qur'an, even without understanding it, is considered a good deed. Second, those who are willing to dwell their time and energy are learning to understand the meaning of such grapheme in a purpose to have knowledge of Islamic values, and not necessarily learn the language to communicate. Third, in many modern pesantren and madrasa today the Arabic language is taught with communicative purposes, hence the students are taught to practice using the language for daily interactions.

The first two notions mentioned earlier generate positive attitudes toward Arabic language, because it is the process of learning considered as good deed. With such attitude, many succeed the process. The latest notion, however, is reported to gain less achievement affirming that the students achievement in learning Arabic language has not demonstated an encouraging results due to the absence of supervision and profesionalism of the teachers [10].

\section{Learning environment}

In learning a language, learners are exposed with various conditions, which some are favourable, and some are not. Quoting Lier, Paiva emphasizes that language learning is a complex system, which is not only something gained due to internal factors (as it is mentioned by nativities), nor something that is resulted from environmental factors only (as it refers to behaviorism) [11]. Hence, language learning always involves internal nature of the learners and also the context of learning, which may refers to everything that goes beyond the learners such as the teaching, the infrastructure, the socio cultural of the learning, etc [12].

Though not the only factor, learning environment has central position in the success of language learning because it refers to many conditions which affect the learning process. As a whole good learning environment, which include appropriate teaching materials and methods, and supported with the positive socio cultural experiences will surely put the language study at ease. At the very minimum, this will create positive atmosphere towards the learning, which in turn encourages positive attitude toward the learning, and most importantly toward the language they learnt.

\section{Learners' Religious Identity}

\subsection{The influence of English on Learners'Identity}

As teenage, madrasa students are pretty much aware of who they are, in other words, they have already developed a particular degree of identity, as they are already associated themselves within particular groups. Growing up in a family and neighbourhood with high intense of religious practices, most of the students are aware of how they should think and behave in accordance with Islamic perspectives. The basic moral values advocated by most muslim growing up in such neighbourhood include brotherhood, selflessness (keikhlasan), simplicity in living (kesederhanaan), and self-sufficiency (kemandirian) [13]. In addition, many of the moslem holding a more traditional view also have somewhat negative attitudes toward modernization, claiming that modernization is associated with the lost of values, and therefore it may challenge the spiritual living [13].

With such believes, when students encounter foreign language learning, they bring along their identity within the process. In English learning, the students learns not just the language but they are also exposed the culture brought by the language. Such exposure will contestate learners identity, as it carries part of modernizations like films, shopping malls, and it also exposes learners to different types of habits, such as parties, clothing, costumes, behaviors, 
and so on. At particular context, there will be at least some adjustment of thought students made to relate with what is being learnt, and it may also trigger the evolvement of identity which may result in different view and behavior.

In short case, learners are reported to be willing to use common expression like yes, hello, mornin, no problem [14]. I would say they are willing to say it and not just they are able to say it, due to an assumption that it takes a courage to say it, as in their environment, saying such expression will threathen their confidence. On the other hand, saying such expression does not suggest that learners embrace the values, as I believe those are common expression easily uttered [14].

In longer case, studies also report that school environment is influential in forming students' identity and English learning does not have negative influence on the process, instead, particular values such as respect, self-confidence, diligence, teamwork and decency are mostly cultivated during the learning process [15]. It can be argued then that the values retrieved in the process are general values set for any types of lives, and therefore it will not conflicted with their beliefs. Furthermore, the targetted lessons and activities in classroom will promote good behavior and therefore such values will be reclaimed as the results. The different ways of life like the party, and other behavior considering not in accordance with their Islamic values are not shown on the learning process, as they probably can be noticed in real life, or through films, at the minimum. This is inline with the result of the study conducted by Clemente and Higgins in 2008 showing that many of English learners in Mexico are willing to say that English is theirs, as they are able to communicate in it, and yet they are not willing to take the cultures that come with it [16].

\subsection{The influence of Arabic Language on Learners'Identity}

The Arabic language learning, on the other hands, offers more positive influence toward learners identity, as Arabic language is already associated with Islam. Their ability to understand Arabic, as Qur'an or hadits verse quoted in the Islamic subject lessons will genarally appreciated, and thus will add to learners' self esteem. Although this kind of understanding is not necessarily cultivated in terms of communication, learners having such skill will be considered as being more solemn, as the basic belief is that you can perform better prayers once you understand it more. In this notion, learners are willingly forming their prefered identity as the identity is not only developed by considering ourselves as the members of that community but it is also imperative to consider how others see us as part of that community. [17]

In terms of communication, Arabic language has been taught in madrasa since the earliest of its establishment [18], yet only in curriculum 2013 that the teaching is targeted for communicative purposes by focusing on teaching Arabic in the four language skills, speaking, writing, listening, and reading [19]. Having the focus for communication sets the Arabic learning from the earlier structural view to become more interactives. This will force learners to have more intearction using the language. Although ideally designed, the target of communicative approach is not easily met [20].

However, the difficulties in cultivating the language does not necessarily identical with the highly positive attitude for the language in a way that it easily encourage learners to acknowledge themself within the groups, and hence form learners' identity. In Islamic institution, the Arabic learning is associated with learning good character, as the reading can be used to promote good characters by introducing Islamic leads and idols [21]. 


\section{Conclusion}

Foreign language learning brings various impact for the learners, not just the ability to use the language for communication, but it will also influence the identity formation of the learners. In this study English and Arabic language is seen as example of foreign language influencing the learners' identity. learners have positive attitude toward both language with tough in different manner. English is mostly seen as the language of modernization and therefore, learners are more careful in cultivatinng the language, though studies report that there is no negative influence of learners' learning English. On the other hands, Arabic language is seen in a more positive attitude in a way that learners are easily acknowledged themselves having the identity related to Arabis language and Islam in general. Though the perception toward both language is somewhat different, the result of language learned aimed at communication undergoes similar result, in a way that there has not been many noticeable achievements reported.

\section{References}

1. S. Gass, \& L. Selinker. Second Language Acquisition: An Introductory Course. Portsmouth: Heinemann. (2001)

2. J. Collentine. \& B.F. Freed. Learning context and its effects on second language acquisition. SSLA 26. (2004)

3. M. Guerrero. Acquiring academic English in one year: An unlikely proposition for English Language learners. Urban Education. 39. (2004)

4. O. Komaria. The History of English Language Teaching in Indonesia. Unpublished Master Thesis - UNIKA Atmajaya (2007)

5. A. Rasjid. Urgensi madrasah di era kontemporer. Jurnal Pendidikan Agama Islam. 1.1 (2013).

6. S. Mappiasse.\& A.J. Sihes. Evaluation of English as a foreign language and its curriculum in Indonesia : A Review. ELT. 7. 10 (2014).

7. Y.R. Khatimah., A Gunawan. \& S. Wachidah. When English Rings a Bell, buku Bahasa Inggris Kelas VII. Pusat Kurikulum dan perbukuan Balitbang: Kementerian Pendidikan dan Kebudayaan Indonesia.

8. R. Batstone. Contexs of engagement: A discourse perspective on 'intake' and 'pushed output". System. 30 (2002)

9. C. Tutyandari. Breaking the silent of the student in an English langueg class, in Proceeding of 53rd TEFLIN International Conference, Yogyakarta, Indonesia (2005)

10. S.Kuraedah, H. Insawan, \& I. Wahyuni. The reality of Arabic learning guidance in Indonesian Islamic senior high schools. IOP Conference Series: Earth and Environmental Science. 175. 1 (2018)

11. V. Paiva. Identity, motivation and autonomy in second language acquisition from the perspective of complex adaptive system, in Identity, Motivation, and Autonomous in Language Learning ed. Garold Muray, et.all. Bristol:Multilingual Matters (2011)

12. P.Y. Gu. Vocabulary learning in second language: Person, task, context, and strategies. TESL-EJ. 7. 2 (2003)

13. R.A. Lukens-Bull. Teaching morality: Javanese Islamic education in a globalization era. Journal of Arabic and Islamic Studies. 3 (2011) 
14. D. Wulandari. Defining language identity of youth learning Islamic studies in traditional pesantren, in Proceeding of the International Conference on Teenager from the Perspective of Literature, Linguistics, and Culture. May $28^{\text {th }}, 2013$. Yogyakarta, Indonesia (2013).

15. M.N.L.Azmi, I. Hasan, A.T. Hidayah, \& N.I. Suhaimi. English language learning, environment, and formation of Islamic self-identity among students in selected religious secondary schools. International Journal of Innovation, Creativity and Change. 11.7 (2020)

16. B. Norton. \& K. Toohey. Identity, language learning, and social change. Language Teaching. 44. (2011).

17. V. Rydland. \& V.G. Aukrust. Identity revealed through talk among young languageminority children in Norwegian classrooms. International Journal of Educational Research. 47. (2008)

18. M.Nasir. Kurikulum madrasah: Studi perbandingan madrasah di Asia. Nadwa:Jurnal Pendidikan Islam. 9. 2 (2015)

19. Q. Nurani. Kurikulum Bahasa Arab Madrasah Tsanawiyah. Unpublished thesis of UIN Sunan Kalijaga Yogyakarta. (2017)

20. W. Nasruddin. Teaching English as a foreign language at madrasah ibtidaiyyah: facts and challenges. Dinamika Ilmu. 15. 1(2015).

21. S. Nasution. Pengembangan kurikulum bahasa Arab di madrasah berbasis karakter. Bahasa dan Seni.44. 2 (2016) 